\title{
Musharka financing for poverty alleviation in Pakistan
}

\author{
Nadeem Iqbal ${ }^{1, *}$, Najeeb Haider ${ }^{2}$, Muhammad Ramzan Akhtar $^{3}$, \\ Sumia Hafiz Abdul Karim ${ }^{4}$ \\ 1 Department of Business Administration, Ghazi University, Dera Ghazi Khan, Pakistan \\ ${ }^{2}$ Department of Statistics, Ghazi University, Dera Ghazi Khan, Pakistan \\ ${ }^{3}$ Faculty of Management and Social Sciences, MAJU, Islamabad, Pakistan \\ ${ }^{4}$ Indus International Institute, Dera Ghazi Khan, Pakistan \\ *E-mail address: drnadeemiqbal@gmail.com
}

\begin{abstract}
Unemployment, with other factors, leads to poverty. Poverty is an important characteristics of the developing countries including Islamic countries. Poverty causes human degradation in all aspects of life. It causes widespread diseaes and ignorance which contributes in lowering physical productivity and income level. In this way, poverty perpetuates overtime. Poverty eradication needs expansion of SMEs. SMEs need less capital and create more jobs in society. Employment opportunities increase as the SMEs spread in the country. The economic impact of SMEs can be measured by their contribution to output, employment, income, investment, export and other economic indicators. But expansion of SMEs needs flow of financial resources. Current arrangement of SMEs are linked to commercial banks. Commercial Banks do not find practicable to finance SMEs because processing case for small loans, their monitoring and recovery is costly to them. A comparison between Grameen Bank Methodology and Sudanees Islamic Bank is discussed in the paper. SMEs are financed through various institutions of Islamic financing. Among their institutions, Musharka financing is an effectiveinstument. Therefore, the paper is interested to explore the issue of Musharka financing for financing SMEs in Pakistan. The paper discusses both theoritcal and practical aspects of Musharka financing. In the above back ground this paper focuses on financial problem in the light of Islamic finance. It is the content of the paper that Islamic financial framework is better alternative to micro credit programmes. To alliviate the poverty, SMEs sector can play a better role which is facing the shortage of credit.
\end{abstract}

Keywords: Unemployment; poverty; Islamic financing; Musharka financing

\section{INTRODUCTION}

Developing countries of the world are facing low level of savings and investments. Growth rate of GDP in developing countries is also very low. But the population growth in the developing countries is higher. But the technology in these countries is very poor and economic resource are very scare. Due to these factors unemployment is increasing. Unemployment, with other factors, leads to poverty. Poverty is an important characteristics of the developing countries including Islamic countries. Poverty causes human degradation in all 
aspects of life. It causes widespread diseaes and ignorance which contributes in lowering physical productivity and income level. In this way, poverty perpetuates overtime.

Poverty eradication needs expansion of SMEs. SMEs need less capital and create more jobs in society. Employment opportunities increase as the SMEs spread in the country. SMEs have great potential to develop because they use less space, less capital oriented, create less pollution, generate greater employment opportunities, use simple technology, and manned with unskilled and semi-skilled labour force. The economic impact of SMEs can be measured by their contribution to output, employment, income, investment, export and other economic indicators. But expansion of SMEs needs flow of financial resources. Current arrangement of SMEs are linked to commercial banks. Commercial Banks do not find practicable to finance SMEs because processing case for small loans, their monitoring and recovery is costly to them. SMEs are financed through various institutions of Islamic financing. Among their institutions, Musharka financing is an effectiveinstument. Therefore, the paper is interested to explore the issue of Musharka financing for financing SMEs in Pakistan. The paper discusses both theoritcal and practical aspects of Musharka financing. In the above back ground this paper focuses on financial problem in the light of Islamic finance. It is the content of the paper that Islamic financial framework is better alternative to micro credit programmes. To alliviate the poverty, SMEs sector can play a better role which is facing the shortage of credit. The rest of paper is organised as follows: section two discusses the role of SMEs in general prospective. Section three discusses Grameen Bank Methodology and problem with this mehology. the section fourth discusses the Islamic financial framwork, section fifth studies the Musharka framwork in theoratical framework, practical implementation, scope in Pakistan, guideline, advantages, and section sixth discusses the conclusion of the study.

\section{ROLE OF SMALL AND MEDIUM ENTERPRISES}

The small and medium scale sector covering wide variety of products is very critical to the soundness of the economy of every country whether developing or developed. The countries, which had realized how significant SMEs, are for sustained growth, are now the tiger economies of the world. In developed countries like USA, UK, Japan etc SMEs account for nearly $80 \%$ of economic activity and employment. So Bernie and Neck have identified the SMEs as source of significant employment potential, revenue generation and technoloical advancement. According to the website ${ }^{1}$, the numbers of SMEs are some of the countries and regions are:

\begin{tabular}{|c|c|c|}
\hline No & Country/Regions & No. of SMEs \\
\hline 1 & USA & 4.7 Million \\
\hline 2 & The United Kingdom & 3.7 Million \\
\hline 3 & European Union & 19.3 Million \\
\hline 4 & The Caribbean & 5 Million \\
\hline
\end{tabular}

\footnotetext{
${ }^{1} \mathrm{Hptt}: / /$ www.accaglobal.com/pdfs/smallbusiness/EESME.doc
} 


\begin{tabular}{|c|c|c|}
\hline 5 & Singopore & 1 Million \\
\hline 6 & Hong Kong & 3 Million \\
\hline 7 & India & 13 Million \\
\hline 8 & Pakistan & 3.2 Million \\
\hline
\end{tabular}

Pakistan has a higher growth rate and very low level of saving and investment. Unemployment ratio is very high due to lower growth rate in the economy so growth of labour exceeds incremental growth of employment in the formal sector. SMEs do not impose foreign exchange due to its simple nature to operate and technology constraints as they use local material and simple techniques. SMEs are socially suitable because they are frequently located inside house premises and involves less frictions. Moreover, the income generated in SMEs favourably affects income distribution.

SMEs are profitable institutions. The high percentage return exhibited by SMEs can be attributed to the capital invested because opportunity cost of labor is close to zero in labor surplus economies like Pakistan. The existence of high rate of return in respect of SMEs has been noted by many studies. One study observes, "It is very rare indeed to find a micro enterprise where the annual return on the capital invested is more than one hundred percent, in real rather than nominal terms, and figure several thousand are not uncommon. It is important to stress again that sums involved are so small that the returns are still miserable in those terms, but relatively they are enormous". Thus, there lies a great poter for improving income and standard of living of the people by promo microenterprises.

SMEs have a great potential to develop, because they are considered to be less capital oriented, consume less space, creat less pollution, generate greater employment opportunities, and are low technology oriented. Employment generation is considered as a major objective of SMEs. It has been analyzed in the perspective of the total labour force: the employed, semi-employed and unemploed persons in the country. SMEs constitute bulk of Pakistan,s business landscape. Nothing portays the reality of Pakistani business environment better than the nature and complexion of its SME sector.

\section{PROBLEMS FACED BY SMES}

Small and medium enterprises (SMEs) are generally and widely known for the creation of comparatively more jobs at a lesser investment. But SMEs sector in Pakistan is facing different types of problems which are as under. The SMEs are facing the problem of financing and funding in pakistan. Deu to lack of financing there are different problems which SME are facing.

SMEs are facing inadequate level of technology and managerial skill. The SMEs usually use the machinary which is obsolete and old fashioned machinery, old plant and outdated technology in Pakistan. There are also problems in marketing and distribution. SMEs purchase the raw material at higher price due to order of small quantities and face difficulties in substituting local products. 
The development of SMEs, as a comparatively less expensive source of employment generation, but it is mostly constrained by credit. The terms and conditions of the credit offered by financial institutions to SMEs are mostly unfavourable, complicated and noncompatible. The volume of available credit is usually very small, and the accessibility of entrepreneurs to credit is usually delayed and discouraging because of lengthy procedural formalities.

There is no agency or other organization within the government which could provide information, counselling and guidance to SMEs about the availability of credit, terms and conditions for obtaining credit, counselling and guidance as to how to get credit, where and when to invest, profitability of the particular industry, and in the case of any problem, how to deal with and tackle it.

The conventional financial institutions avoid to lend mony to SMEs because od highr transaction cost, and risk due to unavailability of collateral with the small units. The financing of SMEs has long been an intractable problem. These enterprises can be established with a small amount of capital. Historically, the local groups, voluntary organization, and local money lenders have been financing income raising activities of the SMEs. But they only meet a small fraction of the total demand for financing due to shortage of resources. They charge extremely high intrest rates and their loaning activities are focused in rural arears. Similarly, special institutions (Grameen Bank of Bangladesh) disbursing concessionary loans to SMEs have turned out to be non-sustainable.

\section{GRAMEEN BANK METHODOLOGY TO FINANCE THE SMES}

Grameen bank beleived that main problem of the poor is lack of access to credit line. So, grameen Bank (GB) provides the loans to poor without any type of collateral assets. GB has been successful in overcoming the problems of informational asymmetry often found in rural financial markets. This bank replaces colleteral by peer pressure and social sanction. Peer monitoring is a system in which loans are given to a group of borrowers who are mutually responsible for repayment and agree others in the group. The key feature of group lending in the joint liability involved. Collective reposibility substitutes collateralised assets. In order to avoid family biase in group control, only one member of the house hold may join a group and relative are not admitted in the same group. At GB, male and female member form seperate groups. The extremely poor can get small loans at GB if they form groups of five people. Each member of the group receives an individual loan; however, they are mutually resposible for all five credits. The bulk of GB,s borrowere are women who constitute the weakest social group among the rural poor. Lending money to women has largely enhanced recoverability for the GB,s loan.

Unlike the convential banks where cutomers visit the bank,s branches, the GB approach is to take banking services to centres and villages. In the centre, members receive the funds, pay the due the installments or fill in any bank requirement. As a result, information asymmmetries decline, as bank employees are usually well informed about problems and achievements as they arise.

Since granting credit and social services to the poor is costely, GB relies on international aid. Grameen Bank receives concessionary loans from international agencies such as IFAD, NORAD, SIDA, ODA, and Ford Foundation. In addition, it also receive loans at concessionery rates from the central bank of Bangladesh. Presently, most funds comes from savings and international agencies. 


\section{PROBLEMS WITH GRAMEEN BANK METHODOLOGY}

Hassan, however, argue that GB is a misnomer; it is not a bank at all. Depostis from individuals and firms account for a small percent of its assets. The bank actually functions as conduit for huge grants from governments and international agencies. That aid is then used as the basis of the credit pyramiding scheme that not only provides micro loans but also funds a feminist social egineering that fights against children and marraige.

GB gets funds at below market rates from donor agencies, and deposits that money in fixed term and short term accounts in commercial bank that pay higher rates. GB makes a huge profit this way. The banks ideological mission requires that a borrower disclose her private life to the bank,s staff. That fact that $93 \%$ of GB,s borrower are women is the part of its social agenda.

If the GB claim to be a private and profitable institution, the obvius question is why the other banks cannot do so. If GB were in fact as profitable as its animators claim, Western banks would be ready to copy the system. Bankers would love to discover that the poor are 98 $\%$ credit worthy.

The success of GB is not free from the influence of external factors. To be effective and sustainable, a credit delivery system also needs a suppertive national policy framework for it to remain autonomous and free from political influence. Forming groups and disbursing group based credit entail high administrative costs. It can be argued, therefore, that GB would not be able to generate enough revenue to cover costs on longer term basis. Therefore GB depends on cheap external credits and donors resources. Reliance on these funds raises serious questions about GB,s sustainability over time.

Grameen bank procedure about providing the fianacing is very costly. To cover the huge expenses, the bank charges the higher rate of interest from the poor which is also critical. In Pakistan poor people are religious minded. They want to follow the sharia law. Islam does not allow the interest. Grameen Bank provides the loan on interest basis which is prohibited in Islam, so the people of Pakistan hesitate to receive the loan on interest basis. It also provides the loan to female $(93 \%)$ clients which is not suitable in Pakistani culture because majority people of Pakistan are Muslims, they do not like their female to mixup with other people as peer group. So this methodology of Grameen Bank is not valid in Pakistan.

So the Grameen bank,s methodology has shortcoming whcih could not fulfill the requiurement of the SMEs sector in solving the problem of financing. An alternative methodolgy of Islamic financial framwork is available which is better alternative for financing the SMEs to alliviate the poverty and to develop the economic growth of the country by solving the problem of credit for SME sector in Pakistan.

\section{AN ISLAMIC FINANCIAL FRAMEWORK - AN ALTERNATIVE METHODOLOGY}

Islam is complete code of life. Al-Quran and Sunnah are main source of Islamic Financial law. Islam not only guides us how to live in society but also guides us how to deal in business to earn profit. Islam wants to establish a balanced society in which justice and benevolence should be prevailed. It requires every one to discharge his obligations towards others. In this way rights of every one are protected. It exhorts the Muslaims to go even furhter by showing benevolence to their brothers. This is general approach of Islam. 
Islam unites all individuals in the bond of universal brotherhood as if they are members of a single family. Each and every individual within this brotherhood is entitled to equal social status. This is summed up by on Hadith of Muhammad (SAW): "Mankind is the family of Allah and the most beloved of them before Him is the one who is best to His family". The main implication of brotherhood is cooperation and mutual help with each other, the AlQuran says "Help ye one an other in righteousness and peity" and "the beleivers, men and women, are protector, one of another" some of Ahadith bring out the significance of cooperaion more explicity: "A muslim is the brother of another musliam. He neither wrongs him nor leaves him without help, nor humiliates him"

In this prospective, financier and clients are members of one brotherhood and, regardless of any group distinition, enjoy the same degree of respect, love and social status. It rules out all such relationship in which financier acts from a position of power and strength and his clients act from the position of social week and needy persons. This motivaion favourably affects demand and supply forces of the financial market. Both parties understand each other interest and thtough fair dealing focus on favourable synergies which facilitate greater use of risk sharing modes of financing.

Islamic banking industry has been rapidly growing since 1980s. One estimate shows that total fund under islamic banking is about 100 billion US dollars. About ninety islamic banks are operating in the private sector through out the world. The islamic banks have adopted the different modes of islamic financing which are as under. ${ }^{2}$

Musharka is finanical partnership where two investors agree to share the principal capital and lator the profit or losses on the proportional basis, according to their initial contribution to the capital. Musharka could be in assets or in working capital. At the end of the production/operation, year/season, the cost of production/operation is deducted from revenue and a certain percentage is earnmarked for management fees.

The Mudarba is a form of partnership in which the borrower works with the capital of others, using only his experience. In the mudarba contract two parties are involved; the money owner (bank) and enterprenuer (client). Profit are divided between the capital owner and the speculator/borrower, who will only loose his effort in case of business failure.s

The benevolent loan (Qard Hassan) is a loan provided for special cases, only the loanee is expected to repay just the principal amount loaned with no additional charges. This type is usually provided in very exceptional circumtances. Murabha is resale of commodity by adding a specific profit margin (determined by bank) to a client who agrees to buy that commidity for the new offered price. Usually, repayment is made in installments to the financier who pay the price to the original supplier of the said commodity. This type of finance is used for fianancing assets or working capital (inputs).

\section{MUSHARAKA FINANCING IN ISLAMIC PERSPECTIVE}

Partnership financing scheme is a key mode of financing in Islamic financial system. It provides alternative financing arrangement which replaces the practice of lending on interest.

The Islamic law prohibits interest based banking. The rationale of prohibition is based on the fact that it assures a fixed return to the financier while the borrower is left to bear the entire business risk. Islam wants to promote justice and equity. Justice demands that the

\footnotetext{
${ }^{2}$ Akhtar, M. Ramzan, "Financing of Micro Enterprises: An Islamic Strategy for Poverty Allevi8ation” Annual journal of International Islamic University Islamabad, Pakistan, Issue No. XI, 2003
} 
financier should share risk with the borrower if he wishes to earn profit. Accordingly, the partnership scheme provides financing on the basis of profit and loss sharing. Profits are shared on pre agreed proportions and loss, if any, is borne by each partner strictly in proportion in to respective capital contribution.

Partnership financing technique offers arrangements that enables financier and borrower to pool their capital to untake business (Ahmad, 1995). It is important to stress that borrower alos provides part of the total cost of the project which varies according to nature of each project funded. In case he does not have cash then the current value of machine labour, rent of building etc contributed by him can be counted towards his share of capital in the partnership. Both financier and client participate in operating the enterprises under thewrit ten agreement.

At the level of the beneficieries, Musharka is a financial relationship which is based on profit and loss sharing. This situation usually protects the small enterprises from external factor i.e. flood, fire, etc for at least someone will share with him any losses. In addition, there is percentage which is usually resevered for the beneficiery to compensate him for his efforts towards managing the business.

Musharka financing is a mode of finance offering an alternative relationship between enterprenuer, which is not based on the traditional relationship which usually exists between the money lender and the borrower. It is a relationship of two enterprenuers who aims to achieve success in their jointly owned business. One of them may have more experience in the concerned field than the other, but in general, the two are sharing the principal capital of the business, and any profits or losses. There is no collateral needed under Musharka, the only guarantee is a well done and careful feasibility study for the business, showing the prospects of success and the possibility of failure.

In Arabian society, musharka and muzdarba type of buiess were done before Islam. Muhammmad (PBHU) also did business of Musharka.

Muslim scholar and experts have discussed four forms of Musharaka type of business. Shirkat-ul-Inan is one type of musharka business and fits into the requirement of modern business protocol. There are different conditions for validity Musharaka contract. Porposed business should be accepted with free will and soumd mind. In the musharka business each paprtner is supposed to be agent of toehr partner. Rate of profit and loss must pre determined and the profit may be equal or unequal according to contract or capital invested.

Musharka could be a continuous one or for a short period (season). The continuous musharka (to the end of the project,s life span) is known as "Musharka Daa'ima" permanent partnership. The other type of musharka is the "Musharka Mutanagisa" Diminidhing partnership and this is when the client is allowed to buy out the bank,s share gradually. In this type of musharka the net profit is shared between partners according to the percentage of their share-capital at the end of each year.

\section{PRACTICAL EXPERIENCE OF MUSHARKA FINANCING IN SMEs: SUDANESE ISLAMIC BANK CASE}

Up to date small enterprises financing has been a challenge, numerous examples of financing scheme have been applied in different developing countries. The advances that have been achieved in financing small enterprises are not without problems. The Sudanese Islamic Bank was established in the in the late 1970s and the early 1980s to implement the Islamic financing system. They have managed to utilise the Islamic financing formulae to venture capital to small enterprises and productive families. The Sudanese Islamic Bank (SIB) is the 
first bank that initiated and opened family specific branches in the urban residential areas to extend capital to small enterprises. A declaration by the bank,s BOD called for the majority of the bank,s operation to be financed through islamic partnership financing. Partnership fiancing covers vertually all types of businesses including trade, agriculture, industry and service. The main idea behind the productive families branches, is the SIB,s believe in family as a productive unit. For increasing family income, it finance SMEs usually located in the house premises. Table shows cosildated view of four projects on the basis of detailed information reported elsewhere(Al-Basri 1995). Almost all the clients expereinced bank dealing for the first time. It shows that both bank and clients share the total profit according to their equity pariciapation in the project. . However, this is not the case in the distribution of management fee. For instance, in the shoe project the client receives the entire amount of management fee while it is distributed equally in ready-made clothes and cooking oil projectII. Typically, 25 to 30 percent of the total net profit is distributed as management fee. The client is benefited from the management fee and from his share of profit on the basis of capital contribution.

MUSHARKA FINANCING OF MICROENTERPRISES

\begin{tabular}{|c|c|c|c|c|c|c|c|c|c|}
\hline \multirow[b]{2}{*}{ Name of project } & \multicolumn{2}{|c|}{ Equity participation } & \multicolumn{2}{|c|}{ Management } & \multicolumn{2}{|c|}{ Equity } & \multicolumn{3}{|c|}{$\begin{array}{l}\% \text { rate of annual return on } \\
\text { investment }\end{array}$} \\
\hline & Bank & Client & Bank & Client & Bank & Client & Bank & Client & Total \\
\hline Ready-made clothes & $\begin{array}{l}75000 \\
(24.6)\end{array}$ & $\begin{array}{r}241997 \\
(75.4)\end{array}$ & $\begin{array}{l}4216.5 \\
(50)\end{array}$ & $\begin{array}{l}4216.5 \\
(50)\end{array}$ & $\begin{array}{l}8318.45 \\
(24.4)\end{array}$ & $\begin{array}{l}2577.55 \\
(75.6)\end{array}$ & 64 & 48 & 54 \\
\hline $\begin{array}{l}\text { Cooking-oil } \\
\text { Production-I }\end{array}$ & $\begin{array}{l}333825 \\
(43.83)\end{array}$ & $\begin{array}{l}400000 \\
(65.18)\end{array}$ & $\begin{array}{c}320.75 \\
(25)\end{array}$ & $\begin{array}{c}9626.25 \\
(75)\end{array}$ & $\begin{array}{l}23360 \\
(45.5)\end{array}$ & $\begin{array}{l}27980 \\
(54.5)\end{array}$ & 32 & 36 & 32 \\
\hline Shoe Production & $\begin{array}{l}175000 \\
(80)\end{array}$ & $\begin{array}{c}44300 \\
(20)\end{array}$ & & $\begin{array}{l}9600 \\
(20)\end{array}$ & $\begin{array}{c}27160 \\
(50)\end{array}$ & $\begin{array}{c}11640 \\
(30)\end{array}$ & 63 & 92 & 89 \\
\hline $\begin{array}{l}\text { Cooking-Oil } \\
\text { Production_II }\end{array}$ & $\begin{array}{l}350000 \\
(64.35)\end{array}$ & $\begin{array}{l}193880 \\
(35.65)\end{array}$ & $\begin{array}{l}6406 \\
(10)\end{array}$ & $\begin{array}{l}6406 \\
(10)\end{array}$ & $\begin{array}{c}32009.5 \\
(62.46)\end{array}$ & $\begin{array}{l}19238.5 \\
(37.541)\end{array}$ & 44 & 55 & 48 \\
\hline
\end{tabular}

Note: $\%$ in brackets.

The table indicates impressive and effective rates of return on total investment which range between 32 percent and 89 percent. It is also observed from the table that minimum profit is 32 percent which is reported by cooking-oil project-I which is favorableable and higher return as compare to the return on interest-based lending in neighbouring countries and own country. The maximum return to the client is 92 percent in shoe production project which is unmatchable return to conventional banking. All of the financed projects were successful which may be observed in the table given above. The experience of client, following-up by the bank, and availability of marketing channels mainly determined success of these projects. Thus the reported evidence shows that musharakah financing scheme provides reasonable returns to small entrepreneurs, which help raise their standard of living and alleviate the poverty in the country. 


\section{PAKISTAN CASE}

Islamic financing is itroduced in Pakistan by regime of General Zia ul Haq. Banking sector has started to converts its products into islamic modes of financing. Musharka and Mudarba were recognised basic mode of financing in islamic banking in Pakistan. State Bank of Pakistan also has provided guidance according to Sharia Law.

Musharaka finaning can finance working capital to do the business according to sharia law. Musharka financing has been providing the working capital to the needs of both small and large firms. Now there are six Islamic Banks in Pakisan which are doing business on this type of islamic modes through out the country. Other conventional banks are also try to open the islamic financing window due to its growth opportunity in the country. Inspite of its vast scope no specific law has so far been enacted to regulate the conduct of Musharaka financing in Pakistan. Defined in general term, Musharaka means an arrangement of business/financing based on the concept of profit! loss sharing in which parties contribute their money, effort, or skills, or combination of them Profits are shared in pre-agreed proportions and loss if any is borne by each partner strictly in proportion to respective capital contribution Musharaka financing is conducted in the light of terms and conditions which are fixed by the partner of business.

\section{ADVANTAGES OF MUSHARKA}

Musharka has many advantages to financing small enterprises. Musharka is a flexible and fair form of financing. The most obvious advantage is protection of the lender against inflation. It also allows for avoidance of the necessity of demanding repayment from people who have already lost their livelihood. It is a mixture of work and capital and used for both production and management. It is great opportunity to increase incomes for those people who have limited limited income by adopting the musharka beacuase it is very suitable for those who have not their own working capital. It is very is suitable mode of financing both working and fixed capital due to its flexibility nature of business. An other feature of mushrka financing is that the lender shares profit as well as losses with the borrower and hence he shares in the business risk. When applying mushaka, bank staff is obliged to closely monitor the business, take part in marketing and this would no doubt broaden their scope of knowledge and develops their business skills which is an other asset to bank.

Musharka does not require collateral guarantee becuase both both parties are involded in the business with their capital and expertise. It does not force to bear heavy burdon of debts an $d$ other kind of obligation. It neither imposes heavy burden, nor it is conditioned by any obligations to pay money to cover losses.

\section{CONCLUDING REMARKS \& POLICY IMPLICATION}

The paper has studied the musharka strategy of Islamic financing. The paper argues that poverty can be addressed by accelerating economic growth brought about the development of SMEs by solving the problem of financing through by Islamic Partnership financing. The writer believes that Islamic Sharka financing within the constraints of the framework will trigger enormous growth of SMEs and consequently poverty will be alleviated on sustainable basis. It is clear from the experienceof Sudanese Islamic Bank of 
introducing Musharka financing for SMEs via its produtive families branches is poineer and unique. It has the potential of solving the major problems facing similar micro credit programme as musharka protects against depletion of resources as a result of inflation, does not threaten the livelihood of the borrower if things go wrong, involves bank staff in the direct assitance of its cleints and develops trust between the client and bank management. Musharka in contrast to the more secure other modes of finance. It also involves the bank staff into the management of the business including marketing of products and this requires special skills and business environment knowledge which might not be available among the staff of such institution.

\section{References}

[1] Abdalla Mustafa Gamal-Eldin (1995). "Partnership Financing for Small Enterprises: Problems and Suggested Improvements" Paper presented to the workshop on Partnership Financing for small enterprises, Cairo, 1995.

[2] Akhtar M. Ramzan (1995). Practice and Prospects of Musharka Financing for Small Enterprises in Pakistan, paper presented to the workshop on partnership Financing for small enterprises, Cairo, 1995.

[3] Akhtar M. Ramzan, Partnership Financing of Microenterprises" International Journal of Social Economics 24(12) (1997).

[4] Akhtar, M. Ramzan, "Financing of Micro Enterprises: An Islamic Strategy for Poverty Alleviation" Annual Journal of International Islamic University Islamabad XI (2003).

[5] El-Basri, DR. M. E. T, Adam, Nawal Abdalla (1995). "The impact of Partnership financing on Enterprises Development: the case Sudanese Islamic Bank (SIB)" paper presented to the workshop on partnership Financing for small enterprises, Cairo, 1995.

[6] GOP, Economic Survey of Pakistan 2003-4.

[7] GOP, Economic Survey of Pakistan 2005-06.

[8] Hassan M. Kabir, Luis Renteria-Guerrer, The experience of Grameen Bank of Bangladesh in Community Development" International Journal of Social Economics 24(12) (1997).

[9] Ibrahim Badr-el-Din A. (1995). Paper presented to the workshop on partnership Financing for small enterprises, Cairo, 1995.

[10] Nourain Asim (1995). “ACORD Credit Programmes in Sudan: The Musharka Experience", Paper presented to the workshop on Partnership Financing for small enterprises, Cairo, 1995.

[11] The State Bank of Pakistan (1982). Detailed Musharka guidelines vide Circular No. 21, of June 30, 1982.

[12] http://www.accaglobal.com/pdfs/smallbusiness/EESME.doc

[13] Nadeem Iqbal, Naveed Ahmad, Zeeshan Haider, Sonia Anwar, International Letters of Social and Humanistic Sciences 5 (2014) 73-80.

[14] Nadeem Iqbal, Naveed Ahmad, Komal Javaid, International Letters of Social and Humanistic Sciences 6 (2014) 60-73. 
[15] Nadeem Iqbal, Naveed Ahmad, Zeeshan Riaz, International Letters of Social and Humanistic Sciences 9 (2014) 14-25.

[16] M. Shoukat Malik, Muhammad Nadeem, International Letters of Social and Humanistic Sciences 10(1) (2014) 9-19. 